
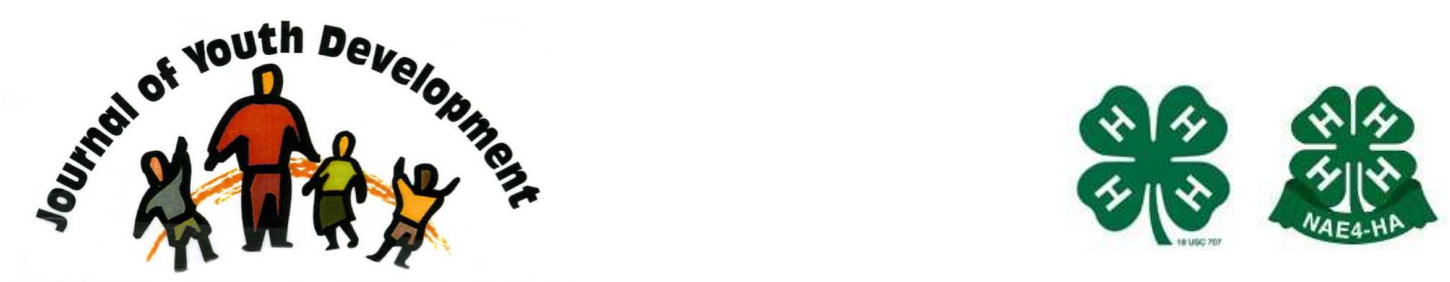

Bridging Research \& Practice

\title{
Investigating the Effects of Brain Respiration on Children's Behavior
}

\author{
Geoffrey K. Leigh \\ University of Nevada Cooperative Extension \\ Las Vegas, NV \\ leighg@unce.unr.edu \\ Cynthia Robinson \\ Henderson Dahn Center \\ University of Nevada Cooperative Extension
}

Steven Bernard Hollingsworth

University of Nevada Cooperative Extension

Reno, NV 


\title{
JOURNAL OF YOUTH DEVELOPMENT \\ bridging research and practice

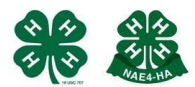

Volume 4, Number 2, Summer 2009

Article 090402FA004

\section{Investigating the Effects of Brain Respiration on Children's Behavior}

\author{
Geoffrey K. Leigh, Cynthia Robinson and Steven Bernard Hollingsworth \\ University of Nevada
}

\begin{abstract}
Building on the increasing number of programs designed to enhance brain development, a program developed in Korea, Brain Respiration, was adapted to a school in Nevada. Classes were offered twice weekly to a class of fourth and fifth grade students with control group classes assessed in the same school. Self-report surveys, teacher observations, and standardized reading and math scores were used to determine effects of the program on the students. Some differences were found in the pretest for the survey and the observation, with control groups scoring higher. There were differences in some post-test scores, with treatment group children scoring higher when differences did occur. There also were differences in the reading and math scores, with control groups scoring higher than the overall treatment group, but not higher when compared to those actively participating in the program. Such differences are discussed as well as other issues possibly influencing the effects.
\end{abstract}

\section{Introduction}

\section{Brain Research and Children's Development}

While cognitive development has been of interest for a long time to those involved in research and educational practices with children, a major focus on brain research expanded dramatically following the landmark work of Gardner (1983), which continues to be extended (Gardner, 1999). In this work, Gardner outlined the argument and foundation for multiple intelligences and its relationship to brain development in children. Following his summary, increasing interest has occurred in how professionals working with children might facilitate development of different types of intelligences rather than assuming only one type.

In schools, teachers, administrators, and parents have become increasingly interested in practices that are related to different types of intelligence development (Fogerty, 2002). They began to look for and develop ways to help children with diverse aspects of intelligence, 
including linguistic, musical, logical-mathematical, spatial, bodily-kinesthetic, and personal (Jensen, 1998, 2001). Even with musical intelligence, many changes and developments have taken place in our understanding of what is critical in terms of the relationship between music and brain development (Skille \& Wigram, 1995; Slade, 2001). In addition, researchers argue convincingly from their work and others that brain and body are closely interconnected, including aspects of memory, which gives us a different view of importance of mind/body connection (Pert, 1997).

While aspects of intelligence were already incorporated in some form within many curricula and could be easily adapted, others, such as spatial, bodily-kinesthetic, and personal were more challenging to incorporate into existing programs. Increasingly, educators have been translating brain research into classroom ideas and practice (Sprenger, 2002; Tileston, 2000; Wolfe, 2001) and even management approaches (Sylwester, 2000). One approach that has a similar objective of increasing brain capacity comes from a different culture (Korea) with a strong focus on building brain use potential in a program called Brain Respiration (Lee, 1998, $2000,2002 a$,). The program is being adapted and offered increasingly in the United States, although this project is the only application that occurs during regular elementary school hours in a public setting.

Increasingly, programs also are being developed to teach children about the basic parts and functions of the brain (Bleeker, 2001). These programs not only include information and activities, but also fun games to help with the actual development of the brain while also learning about it as an important part of our bodies (Chudler, 2001). Some of these activities include other aspects of intelligence, such as music, to stimulate multiple parts of the brain through fun activities (Lee, 2002a).

The Brain Respiration (BR) approach that was evaluated in this study is a system of physical and mental exercises along with an active focusing of the body's natural energy to open up the meridian system of the body. Such activities increase health, vitality, and reduce everyday stress in people's lives. It was developed based on an ancient Korean tradition, yet updated to include modern techniques from science and health. The program makes people more sensitive to the energy of the body and emotions in order to give greater freedom to choose our responses with everyday interactions and events, especially in terms of focusing attention in young children as well as adults. An additional benefit is that BR also seems to have very positive social and interactional effects on adults and children who participate on a regular basis (Lee, 2002a), such as being more peaceful in their interactions. This approach continues to expand and develop in order to help students realize the potential and power of their brain and their being (Lee, 1999a, 1999b, 2002b) as well as providing them a new way to see themselves and solve personal, interactive, and community problems (Lee, 2000). There are many testimonials about the positive effects of this practice, mostly from adults (Lee, 1997, 1998, 1999b), with some increasing evidence to support the ideas (Lee, 2002a). Yet little systematic evaluation has taken place with programs being offered in the United States.

There are now several studies, however, that have been done on BR in Korea. For example, Yu and Chang (1998) conducted research with 282 students in three elementary schools and one junior high school in Seoul, Korea. The researchers divided the total group into an experimental group (138 students receiving the BR method) and a control group (144 students in the same four schools as the experimental group but receiving no intervention). Four assessments were used with both group of students, including an assessment for emotional stability, emotional maturity, short-term memory, and intuition. The BR program was conducted for 5-10 minutes 
every day for eight weeks with the experimental group. The second group was used to control for maturity effects during that time. Based on an ANOVA test controlling for learning ability, there were differences found in emotional maturity, short-term memory, and intuition, but no differences were found in emotional stability. With only a short intervention on a daily basis for eight weeks, differences were found that were above chance, with important implications regarding children's learning.

Two other studies focused on the effects of BR training on the brain activity of Korean elementary school children (Kim, Kim, et al., 2001; Kim, Choi, et al., 2001). Both studies used the same students, a training group and a control group, each including 12 children. The children in the training group were taught brain respiration and practiced the techniques for an hour twice a week for a period ranging from 4 to 14 months. There were significant differences between the two groups, with children trained in BR maintaining more tranquil and higher alpha states (Kim, Kim, et al., 2001). There seems to be some indication that BR training activates brain functioning through changes in activity of the frontal association area where higher mental integration and creative activities occur, along with more relaxed states of the brain (Kim, Choi, et al., 2001).

Finally, Hong (1998) investigated the effects of BR on a group of 126 elementary and middle school youth during an eight-day camp. This camp was specifically designed as a BR camp to develop the mind with two groups of youth, a beginning group ( 88 youth) and an intermediate group (38 youth). In this case, the children participated in exercises three times a day, with other aspects of training occurring at other times. These youth became more sensitive, learned about their body and mind, developed greater focus on long term goals, and felt greater confidence and happiness. This study was more of an experimental demonstration with little systematic evaluation, but the qualitative information from the students was very positive and consistent with other investigations.

From the research done in Korea, it appears that the BR method has positive effects on school performance, changes in development and behavior, brain functioning and stress reduction. Besides the effects of doing some exercise, methods such as BR seem to have much greater impacts than other approaches on both behavior and individual health. Additional research needs to be done, including a full-scale study, as suggested by Yu and Chang (1998). Yet the initial findings are suggestive of important and pervasive impacts from this method, especially with young children.

A focus of the present study was to see if the BR program could influence the behavior of children in a public school as well as influence the reading and math scores from a standardized test. Based on the previous research, it was expected that children participating in the BR program would be better able to focus their attention, would exhibit greater creativity, feel healthier, act more peacefully and kind to others, and would perform better on standardized reading and math tests.

\section{Methods}

\section{Overview of the Program}

The BR program consists of three areas: Wake-Up Gym exercises, Energy Focusing activities, and Brain Building exercises (Hayes, Lampi, \& Leigh, 2002). While the original design of the program was to conduct these activities 5-10 minutes three times a week during the regular classroom period, the program was revised to provide greater opportunity for the children to 
participate in these exercises in more depth and for a longer period of time. The program used with this evaluation included two 50 minutes periods twice a week with both the fourth and fifth grade classes. All of the children in both classes participated in the program in varying degrees.

The Wake-Up Gym (a stretching program to stimulate and open the body's meridian system, stimulate internal body organs, and increase blood and oxygen flow through the body as well as to the brain) was conducted with all the children for about five minutes during the opening ceremonies of the school. However, these exercises also were done almost daily and in more depth during the regular program for the children in the treatment group.

The BR program also included exercises to practice energy focusing and thereby a focusing of attention as well. School work requires a focusing of energy and attention, but ypouth often do not know how to do it well, nor are they experienced doing this. The BR practice helps them learn how to get more in touch with the energy of their body, learning to focus it and their attention in fun and interesting ways. In addition, there were a variety of activities that created a more direct stimulation of the brain and expanding the use of the brain. These included simple hand or arm exercises where different hands or arms were doing different or opposite tasks, activities that included problem solving, and even a direct energy stimulation of the brain. Art and music activities were also included to create more connections between the left and right hemispheres of the brain or different pathways in the brain.

\section{Participants}

The participants in this project were two fourth grade and two fifth grade classes at an urban elementary school in the Southwestern part of the United States. This school is in a lower economic section of the city, with $93 \%$ of the children receiving free lunches. It also is an area of the city where the parents experience many challenges, with the children also being faced with many difficulties. This school also is composed primarily of minority students, with $68 \%$ African American, 28\% Hispanic, and 4\% Caucasian.

With only two classes in each grade, one was selected by the school principal to participate in the BR program (the treatment group) and the other class was used as a control group. Students in all four classes were asked to complete a self-report questionnaire at the beginning and at the end of the program. All four teachers completed an observational form for each student in her/his class just prior to the beginning of the program and again at the end of the program, approximately four months later.

Students participated in the program during their scheduled art class and one of the two physical education classes during the week. Each class lasted 50 minutes per period. During this time, physical, art, and problem solving activities were used to stimulate physical, mental, and creative aspects of the children's brains. They also reviewed parts of the brain, their function, as well as brain stimulating exercises.

\section{Measures}

There were four different measures that were used in the evaluation of this program. First, two instruments were developed to assess whether fourth and fifth grade children saw themselves any differently in several areas and whether teachers also saw any change in children's behaviors in these same areas. The same ten questions were asked of the children (self-report) and the teachers (observational report). These scales included questions about the child's ability to pay attention to details, stay on task, ignore external distractions, keep their attention on their work, and maintain attention during group activities. It also included questions about 
interacting peacefully with others, showing creativity, exhibiting self-confidence, being cooperative and kind with others, and feeling healthy and flexible (see Table 4). These latter questions were other intended outcomes from the BR program beyond school performance issues. The alpha reliability scores for these scales were quite good for the student pre-test (.73) and the post-test (.78), and they were very strong for the teacher observational pre-test report (.96) and the post-test report (.97).

After receiving permission from the parents, scores from the Educational Testing Service Formative Assessment Item Bank were used to look at the impact of the program on school performance in reading and math (Educational Testing Service, 2009). These tests are given to the children every year to measure school performance, and the results were simply used to look at possible impacts from the program. While the BR program does not specifically train for improved reading and math performance, we were curious as to whether such impacts could be seen from the program. Fortunately, there were three assessment periods for both reading and math during the year. The first assessment occurred at the beginning of the school year and the second one just prior to the beginning of the program, allowing us to see how both classes performed before the program even began. The third test was conducted about three months into the program and about three weeks prior to the end of the program. Thus, the schedule of the assessments did not fit with the completion of the program, but it was a close to the end as possible given the structure and constraints on the elementary school. This was one difficulty in the structure of the evaluation of the program.

Because the program was begun later in the school year, many of the students were resistant to the program at first, especially with the fifth grade class. There were, however, only a small group of students (approximately seven in the fourth grade and seven in the fifth grade out of a class of 30-32) who maintained the resistance and had very little participation in the program. Therefore, as a check for effectiveness from actual program participation, scores were made for each student as to the level of participation (very little or none, somewhat, and quite a bit) at the end of the program and entered into the data set as a control variable. This score was done independently from the teacher, who did not know the participation level of the students, as they did not attend the classes themselves.

Two different types of analysis were conducted to look at group differences (Independent Samples T-Test) and change over time (Paired Samples T-Test). In addition to using the total scores for the student and teacher scales, analysis of group differences for individual items also was conducted to look at where the strongest changes took place, if any.

\section{Results}

The results of this evaluation provided mixed support for the expected outcomes. It was expected, for example, that students participating in the BR program would be better able to focus their attention, would exhibit greater creativity, feel healthier, and act more peacefully and kind to others than the control students. Generally, these expected results were supported by the study.

Students in the control group scored higher on the pre-test. Because of the resistance with a few students, a second analysis was conducted using only those students who participated somewhat or a lot in the program. This was done to see if there were effects when children participated more actively in the program ("Active Only" in Tables 1 - 4). 
Table 1

Mean Comparisons by Groups

\begin{tabular}{|c|c|c|c|c|c|c|c|c|c|c|c|}
\hline Group & Variable & $\begin{array}{l}\text { Group } \\
\text { mean }\end{array}$ & $n$ & $\mathrm{t}$ & $\begin{array}{l}\text { Sig. } \\
\text { level }\end{array}$ & Group & Variable & $\begin{array}{l}\text { Group } \\
\text { mean }\end{array}$ & $n$ & $\mathrm{t}$ & $\begin{array}{l}\text { Sig. } \\
\text { level }\end{array}$ \\
\hline All & $\begin{array}{l}\text { Student } \\
\text { Pretest }\end{array}$ & $\begin{array}{l}1=38.63 \\
2=35.08\end{array}$ & $\begin{array}{l}41 \\
60\end{array}$ & 2.907 & .01 & All & $\begin{array}{l}\text { Student } \\
\text { Posttest }\end{array}$ & $\begin{array}{l}1=39.09 \\
2=40.35\end{array}$ & $\begin{array}{l}56 \\
52\end{array}$ & -1.091 & $\mathrm{~ns}$ \\
\hline $\begin{array}{l}\text { Active } \\
\text { Only }\end{array}$ & $\begin{array}{l}\text { Student } \\
\text { Pretest }\end{array}$ & $\begin{array}{l}1=38.63 \\
2=34.98\end{array}$ & $\begin{array}{l}41 \\
47 \\
\end{array}$ & 2.955 & .01 & $\begin{array}{l}\text { Active } \\
\text { Only }\end{array}$ & $\begin{array}{l}\text { Student } \\
\text { Posttest }\end{array}$ & $\begin{array}{l}1=39.09 \\
2=41.32\end{array}$ & $\begin{array}{l}56 \\
44\end{array}$ & -1.979 & .05 \\
\hline All & $\begin{array}{l}\text { Teacher } \\
\text { Pretest }\end{array}$ & $\begin{array}{l}1=36.40 \\
2=31.47\end{array}$ & $\begin{array}{l}53 \\
60 \\
\end{array}$ & 2.693 & .01 & All & $\begin{array}{l}\text { Teacher } \\
\text { Posttest }\end{array}$ & $\begin{array}{l}1=39.00 \\
2=38.17\end{array}$ & $\begin{array}{l}51 \\
60 \\
\end{array}$ & .438 & ns \\
\hline $\begin{array}{l}\text { Active } \\
\text { Only }\end{array}$ & $\begin{array}{l}\text { Teacher } \\
\text { Pretest }\end{array}$ & $\begin{array}{l}1=36.40 \\
2=34.91\end{array}$ & $\begin{array}{l}53 \\
46 \\
\end{array}$ & .856 & ns & $\begin{array}{l}\text { Active } \\
\text { Only }\end{array}$ & $\begin{array}{l}\text { Teacher } \\
\text { Posttest }\end{array}$ & $\begin{array}{l}1=39.00 \\
2=43.13\end{array}$ & $\begin{array}{l}51 \\
46 \\
\end{array}$ & -2.811 & .01 \\
\hline
\end{tabular}

Table 2

Mean Comparisons by Groups

\begin{tabular}{|l|l|l|c|c|c|}
\hline Group & Variables & Group Mean & $\mathrm{n}$ & $\mathrm{t}$ & Sig. level \\
\hline All & Read1 & $1=50.09$ & 54 & 1.282 & $\mathrm{~ns}$ \\
& & $2=45.53$ & 55 & & \\
\hline Active Only & Read1 & $1=50.09$ & 54 & .634 & $\mathrm{~ns}$ \\
& & $2=47.64$ & 44 & & \\
\hline All & Read2 & $1=52.80$ & 56 & 1.621 & $\mathrm{~ns}$ \\
& & $2=46.38$ & 56 & & \\
\hline Active Only & Read2 & $1=52.80$ & 56 & 1.242 & $\mathrm{~ns}$ \\
& & $2=47.58$ & 45 & & \\
\hline All & Read3 & $1=48.64$ & 55 & 2.216 & .03 \\
& & $2=40.89$ & 57 & & \\
\hline Active Only & Read3 & $1=48.64$ & 55 & 1.583 & $\mathrm{~ns}$ \\
& & $2=42.67$ & 45 & & \\
\hline All & Math1 & $1=50.89$ & 54 & 1.342 & $\mathrm{~ns}$ \\
& & $2=45.98$ & 55 & & \\
\hline Active Only & Math1 & $1=50.89$ & 54 & .916 & $\mathrm{~ns}$ \\
& & $2=47.32$ & 44 & & \\
\hline All & Math2 & $1=44.48$ & 56 & 1.398 & $\mathrm{~ns}$ \\
& & $2=40.25$ & 57 & & \\
\hline Active Only & Math2 & $1=44.48$ & 56 & 1.215 & $\mathrm{~ns}$ \\
& & $2=40.42$ & 45 & & \\
\hline All & Math3 & $1=50.09$ & 55 & 2.316 & .02 \\
& & $2=43.04$ & 57 & & \\
\hline Active Only & Math3 & $1=50.09$ & 55 & 1.522 & ns \\
& & $2=45.07$ & 45 & & \\
\hline
\end{tabular}


Table 3

Mean Comparisons over Time

\begin{tabular}{|l|l|l|c|c|c|}
\hline Group & Variables & Means & $\mathrm{n}$ & t score & Sig. level \\
\hline Control & $\begin{array}{l}\text { Student pretest }- \\
\text { Student posttest }\end{array}$ & $\begin{array}{l}1=38.63 \\
2=40.32\end{array}$ & 41 & -1.490 & $\mathrm{~ns}$ \\
\hline Treatment (All) & $\begin{array}{l}\text { Student pretest }- \\
\text { Student posttest }\end{array}$ & $\begin{array}{l}1=35.43 \\
2=40.59\end{array}$ & 51 & -5.793 & .001 \\
\hline $\begin{array}{l}\text { Treatment } \\
\text { (Active only) }\end{array}$ & $\begin{array}{l}\text { Student pretest }- \\
\text { Student posttest }\end{array}$ & $\begin{array}{l}1=34.75 \\
2=41.32\end{array}$ & 44 & -9.984 & .001 \\
\hline Control & $\begin{array}{l}\text { Teacher pretest - } \\
\text { Teacher posttest }\end{array}$ & $\begin{array}{l}1=36.50 \\
2=39.19\end{array}$ & 48 & -4.529 & .001 \\
\hline Treatment (All) & $\begin{array}{l}\text { Teacher pretest - } \\
\text { Teacher posttest }\end{array}$ & $\begin{array}{l}1=31.47 \\
2=38.17\end{array}$ & 60 & -9.312 & .001 \\
\hline $\begin{array}{l}\text { Treatment } \\
\text { (Active only) }\end{array}$ & $\begin{array}{l}\text { Teacher pretest - } \\
\text { Teacher posttest }\end{array}$ & $\begin{array}{l}1=34.91 \\
2=43.13\end{array}$ & 46 & -11.812 & .001 \\
\hline
\end{tabular}

Table 4

Mean Comparisons over Time

\begin{tabular}{|l|l|l|c|c|c|}
\hline Group & Variables & Means & $\mathrm{n}$ & t score & Sig. level \\
\hline Control & Read1 - Read2 & $\begin{array}{l}1=50.09 \\
2=53.17\end{array}$ & 54 & -1.211 & $\mathrm{~ns}$ \\
\hline Treatment (All) & Read1 - Read2 & $\begin{array}{l}1=45.69 \\
2=45.96\end{array}$ & 54 & -.137 & $\mathrm{~ns}$ \\
\hline $\begin{array}{l}\text { Treatment } \\
\text { (Active only) }\end{array}$ & Read1 - Read2 & $\begin{array}{l}1=47.64 \\
2=47.68\end{array}$ & 44 & -.021 & $\mathrm{~ns}$ \\
\hline Control & Read2 - Read3 & $\begin{array}{l}2=53.05 \\
3=48.64\end{array}$ & 55 & 1.767 & $\mathrm{~ns}$ \\
\hline Treatment (All) & Read2 - Read3 & $\begin{array}{l}2=46.38 \\
3=41.20\end{array}$ & 56 & 2.011 & .05 \\
\hline $\begin{array}{l}\text { Treatment } \\
\text { (Active only) }\end{array}$ & Read2 - Read3 & $\begin{array}{l}2=47.58 \\
3=42.67\end{array}$ & 45 & 1.643 & $\mathrm{~ns}$ \\
\hline Control & Math1 - Math2 & $\begin{array}{l}1=50.89 \\
2=44.85\end{array}$ & 54 & 3.562 & .001 \\
\hline Treatment (All) & Math1 - Math2 & $\begin{array}{l}1=45.98 \\
2=40.33\end{array}$ & 55 & 2.718 & .01 \\
\hline $\begin{array}{l}\text { Treatment } \\
\text { (Active only) }\end{array}$ & Math1 - Math2 & $\begin{array}{l}1=47.32 \\
2=40.34\end{array}$ & 44 & 3.007 & .01 \\
\hline Control & Math2 - Math3 & $\begin{array}{l}2=44.82 \\
3=50.09\end{array}$ & 55 & -3.269 & .002 \\
\hline Treatment (All) & Math2 - Math3 & $\begin{array}{l}2=40.25 \\
3=43.04\end{array}$ & 57 & -1.628 & $\mathrm{~ns}$ \\
\hline $\begin{array}{l}\text { Treatment } \\
\text { (Active only) }\end{array}$ & Math2 - Math3 & $\begin{array}{l}2=40.42 \\
3=45.07\end{array}$ & 45 & -2.469 & .02 \\
\hline
\end{tabular}

The higher scores for the control group occurred whether looking at the total treatment group or those who actively participated in the treatment group. There also was a difference with the teacher observations, with the control group scoring significantly higher than the total treatment group on the pre-test, although that was not true for those students who were active in the program. 
With the post-test scores, there was no significant difference between the control and total treatment group because of the significant increase in the post-test scores of the treatment group. For the participating treatment group, the increase was significantly higher than the control group, reversing the pattern of the pre-test differences. A similar pattern was found with the teacher observations. With the increase in scores for the total treatment group, the significant difference found in the pre-test scores was eliminated. For the participating treatment group, there emerged a significantly greater average for the treatment group than the control group for the overall observation scale scores.

When looking at changes over time with the student self-report surveys (Table 3 ), there was a significant increase with the total treatment group and the Participants Only treatment group from pre-test to the post-test, but no significant difference with the control group. With the teacher observations, there was a significant difference with all three groups. The greatest differences, however, were with the treatment groups, especially those who participated in the BR program.

In order to look at where the greatest differences occurred with the post-test questions on the student self-report and the teacher observations, group difference tests were run for each of the ten questions on both scales. Interestingly, where there were significant differences between the control group and the participating treatment group questions, they were similar for the student and teacher reports (see Table 5). 
Table 5

Group Comparison for Individual Student and

Teacher Question on the Post-test

\begin{tabular}{|c|c|c|c|c|c|}
\hline \multirow[t]{10}{*}{$\begin{array}{l}\text { Student } \\
\text { responses }\end{array}$} & Attention to details & $\begin{array}{l}1=56 \\
2=44\end{array}$ & $\begin{array}{l}3.75 \\
4.32\end{array}$ & -2.764 & .01 \\
\hline & Peaceful with others & $\begin{array}{l}1=56 \\
2=44\end{array}$ & $\begin{array}{l}3.55 \\
4.02\end{array}$ & -2.274 & .03 \\
\hline & Show creativity & $\begin{array}{l}1=56 \\
2=44\end{array}$ & $\begin{array}{l}3.78 \\
4.16\end{array}$ & -2.331 & .03 \\
\hline & Stay on task & $\begin{array}{l}1=56 \\
2=44\end{array}$ & $\begin{array}{l}3.79 \\
4.20\end{array}$ & -2.212 & .03 \\
\hline & Self-confidence & $\begin{array}{l}1=56 \\
2=44\end{array}$ & $\begin{array}{l}4.30 \\
4.41 \\
\end{array}$ & -.551 & Ns \\
\hline & Ignore Distractions & $\begin{array}{l}1=56 \\
2=44\end{array}$ & $\begin{array}{l}3.80 \\
3.84\end{array}$ & -.191 & Ns \\
\hline & $\begin{array}{l}\text { Cooperation and } \\
\text { kindness to others }\end{array}$ & $\begin{array}{l}1=56 \\
2=44\end{array}$ & $\begin{array}{l}3.72 \\
4.11 \\
\end{array}$ & -1.979 & .05 \\
\hline & $\begin{array}{l}\text { Attend when } \\
\text { interested }\end{array}$ & $\begin{array}{l}1=56 \\
2=44\end{array}$ & $\begin{array}{l}4.30 \\
4.41\end{array}$ & -.528 & Ns \\
\hline & Healthy and flexible & $\begin{array}{l}1=56 \\
2=44\end{array}$ & $\begin{array}{l}4.11 \\
4.30\end{array}$ & -.858 & Ns \\
\hline & $\begin{array}{l}\text { Attention in group } \\
\text { activities }\end{array}$ & $\begin{array}{l}1=56 \\
2=44\end{array}$ & $\begin{array}{l}3.66 \\
3.70\end{array}$ & -.227 & Ns \\
\hline \multirow[t]{10}{*}{$\begin{array}{l}\text { Teacher } \\
\text { observations }\end{array}$} & Attention to details & $\begin{array}{l}1=51 \\
2=46\end{array}$ & $\begin{array}{l}3.43 \\
4.22\end{array}$ & -4.312 & .001 \\
\hline & Peaceful with others & $\begin{array}{l}1=51 \\
2=46\end{array}$ & $\begin{array}{l}3.92 \\
4.50 \\
\end{array}$ & -2.936 & .01 \\
\hline & Show creativity & $\begin{array}{l}1=51 \\
2=46\end{array}$ & $\begin{array}{l}3.88 \\
4.28 \\
\end{array}$ & -2.550 & .01 \\
\hline & Stay on task & $\begin{array}{l}1=51 \\
2=46\end{array}$ & $\begin{array}{l}3.51 \\
4.20\end{array}$ & -3.356 & .001 \\
\hline & Self-confidence & $\begin{array}{l}1=51 \\
2=46\end{array}$ & $\begin{array}{l}4.04 \\
4.28 \\
\end{array}$ & -1.491 & Ns \\
\hline & Ignore Distractions & $\begin{array}{l}1=51 \\
2=46\end{array}$ & $\begin{array}{l}3.53 \\
4.07\end{array}$ & -2.411 & .02 \\
\hline & $\begin{array}{l}\text { Cooperation and } \\
\text { kindness to others }\end{array}$ & $\begin{array}{l}1=51 \\
2=46\end{array}$ & $\begin{array}{l}4.04 \\
4.41 \\
\end{array}$ & -1.966 & .05 \\
\hline & $\begin{array}{l}\text { Attend when } \\
\text { interested }\end{array}$ & $\begin{array}{l}1=51 \\
2=46\end{array}$ & $\begin{array}{l}4.10 \\
4.28\end{array}$ & -1.107 & Ns \\
\hline & Healthy and flexible & $\begin{array}{l}1=51 \\
2=46\end{array}$ & $\begin{array}{l}4.49 \\
4.72 \\
\end{array}$ & -1.813 & Ns \\
\hline & $\begin{array}{l}\text { Attention in group } \\
\text { activities }\end{array}$ & $\begin{array}{l}1=51 \\
2=46\end{array}$ & $\begin{array}{l}4.06 \\
4.33\end{array}$ & -1.590 & Ns \\
\hline
\end{tabular}

For the student survey, significant differences occurred for attention to details, acting peacefully with others, showing creativity, staying on task, and being cooperative and kind to others. Besides these same five questions for both student reports and teacher observations, there also was a significant difference in the student's ability to ignore distractions between the two groups according to the teachers at the time of the post-test. While teachers observed a difference in students, they did not seem to identify nor did they report such a difference. 
A somewhat different picture for the effects of BR emerges when investigating the standardized reading and math test data. There was no significant difference between the treatment and control group with the first reading assessment (see Read1 in Table 2) or with the second reading assessment (Read2). In addition, there was no significant increase from the first to the second assessment (see Read1-Read2 in Table 3). There also were no significant differences in the math scores from the first to the second assessment (Math1 \& Math2 in Table 2), but there was a significant decline in math scores for all groups between the two assessments (Math1Math2 in Table 4).

When looking at those who were active in the program, there still was no significant difference between groups at the two assessment periods or any significant changes from the first to the second assessment period for reading scores, but there also was a significant decline in the math scores for this group of children.

There was a difference between the two groups at the third reading and math assessment period. However, with reading, the difference occurred only for the total treatment group and was in the opposite direction as expected. This decrease in scores was not so much a decline in reading ability but a lack of increase in performance given the greater expectation for reading by the end of the school year. What is clear is that the active BR students and the control group performed better in reading than those who were not active in the BR program, given the lack of significant difference between the reading scores of the active treatment group and the control group.

With the math scores, there was a difference between the total treatment and control group, but it was the control group who had the higher average in scores. There was no significant difference, however, when comparing the participating treatment group with the control group. In addition, there was an increase in the scores from the second to the third assessment, but there was a significant increase only for the control group (which had the highest mean) and for those who were active in the BR program. When the total treatment group was considered, there was no significant increase in average math scores.

It was the control group who performed the best over the year in reading and math scores. There is some support, in an indirect manner, that the BR program may have been helpful in the performance of those who participated. Yet the program did not have a greater effect even on those participating when looking at standardized test scores in comparison to the control group. There are some possible explanations for these results, which will be described in the Discussion section.

\section{Discussion}

From the beginning, we wanted to see if we could influence the behavior and attention focusing of this group of elementary school children, as well as increase the reading and math scores with a 12 week program. We were not able to significantly increase the reading and math scores, but we were able to influence their behavior and attention focusing, which may be as important, or more important, in the long run.

Where effects from the BR program were seen, they occurred with both the student self-report of behaviors and the teacher observation of behaviors. While the control group also had the higher scores on the pre-test for self report and teacher observations, it was the participating treatment group that had the highest scores for the student survey and the teacher 
observation. They also exhibited the highest changes in scores over the four month period, again suggesting that the BR program had some immediate effects in this area. These findings are strengthened when the results are consistent across the two different methods (self-report and observation).

What also is interesting and strengthening of the findings is that the differences were quite similar for the individual questions on the student survey and the teacher observation. Some of these differences had to do with the focusing of attention to details and staying on task. In addition, however, there were differences in the reports of students behaving more peacefully, cooperating and showing kindness to others, and exhibiting more creativity. All three of these latter student characteristics were important aspects of the program and were supported by the results of both the student as well as the teacher reports.

While it was anticipated that students would perform better on reading and math tests after participating in the BR program, this did not turn out to be supported with this sample of students. Those who participated in the program did as well as the control group (or had a similar decline, as was the case in the reading scores from the second to the third assessment and math scores from the first to the second assessment), and they seemed to do better than those who did not participate. However, the students who did not participate in the BR program also may not have participated as much in class. While they were dropped out of the second analysis only because they were not as active in the treatment program, they also may have been the weaker students in general and were participating less in any school activities. Further analysis revealed that they had lower means than those who participated, although the only significant differences were with reading at the first assessment and math at the third assessment. It also is possible that the BR program helped students do better than they otherwise might have done. What is clear is that with this sample, the BR program did not help students do better than the control group in either the reading or math performances on a standardized test.

The group average test scores indicated that the $4^{\text {th }}$ and $5^{\text {th }}$ grade control classes scored better than the two treatment classes. Even when all the classes experienced a decrease in reading scores from the second to the third assessment, the control group classes still has a higher average. The same is true for the decrease in math scores from the first to the second assessment, as well as the increase in math scores from the second to the third assessment. In each case, the average score was higher for the control group. The BR program did not have an effect to overcome such differences.

One reason for the lack of observed effect may have to do with the timing of the third assessment. It took time to move the children beyond the initial assessment, and some of the strongest effects of the program from a qualitative assessment seemed to take place in the last month. If the test were given at the very end of the year, there may have been a little more difference in impact. It also may be that while the BR program seems to effect some areas related to test performance, such as increased attention to details or staying on task, these effects may not have generalized to the test-taking situation without greater emphasis on such application. While the application was done to a small extent, more direct application may be important. It also may be that the changes in student behavior may take more time to generalize to situations such as taking tests or other more stressful situations.

Another possible explanation for the lack of difference in the reading and math assessment compared to the student and teacher observations may be related to the final activity of the 
program. Students in the BR program were given an opportunity to participate in one of three activities that later were performed in an assembly for the entire elementary school as well as many attending parents at the end of the academic year. These activities involved a slow martial art demonstration as a group (a type of tai chi performance), where the students performed moves using their energy to guide them in unison. A second activity was a dance, demonstrating some of the exercises and class activities to a rhythm and blues song. The third group developed a rap performance as a group, picking their music and writing the words that identified something each had learned about the brain and about themselves from the class. In this latter case, they also decided as a group how each student's written piece would fit into the group's performance, the sequence of the participation, and body movements and staging of the performance. In many ways, the development of this activity seemed to increase the internalization of things they had learned in class as well as the children's confidence in their own abilities.

The final student report and the teacher observations were done during the last week of school as the students were doing final preparations and demonstrating the performance for others, even with each other during dress rehearsal. The same students who had not participated in the BR program had difficulty and ended up not participating in the performance activities because they did not want to cooperate with the group practices. This difference in timing of the reading and math assessments almost three weeks prior to the final performance and the student/teacher reports may have something to do with the differences in impact of the program seen in the student and teacher reports in contrast to the standardized assessments.

As indicated earlier, the results provide mixed support for the effects of BR on elementary school children. There seems to be effects of BR according to the reports of the students and the observations of their teachers. It also appears that such effects are greatest when students have more active participation, which generally is true of any effective program. On the other hand, there does not seem to be support from this project for effects of the program on test performance, although it may have helped some do as well as the control group.

\section{Recommendations}

While there were limitations to this study, there also is sufficient support to warrant further investigation of the effectiveness of Brain Respiration on children. It will be important to incorporate other measures, including other standardized tests or actual measures of creativity. It also would be important to look at the effects when the program is implemented at or near the beginning of the school year rather than when schedules and patterns already are established with the school children. Finally, it would be important to allow more time for generalization of the learned skills to situations that are more stressful and anxiety provoking, such as standardized test taking periods, especially when such tests have implications for the evaluation of teachers and entire schools. At the same time, BR shows promise in impacting students in several important ways and more comprehensively than most single programs. 
Table 6

Student Self-Report Survey

\begin{tabular}{|c|c|c|c|c|c|}
\hline OW OFTEN DO YOU: & $\begin{array}{c}\text { Never } \\
\text { Or rarely } \\
\text { always }\end{array}$ & $\begin{array}{l}\text { Once in } \\
\text { a while }\end{array}$ & $\begin{array}{c}\text { Sometimes } \\
\text { or some of } \\
\text { the time }\end{array}$ & $\begin{array}{l}\text { Most of } \\
\text { the time }\end{array}$ & $\begin{array}{c}\text { Very } \\
\text { often ol } \\
\text { almost } \\
\text { always }\end{array}$ \\
\hline
\end{tabular}

1. Always follow instructions and not make mistakes
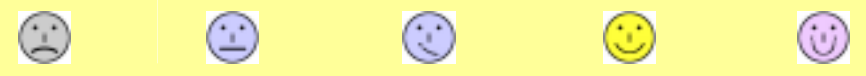

2. Behave peacefully and nice to others
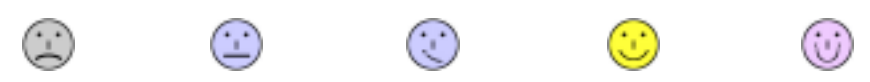

3. Come up with different ways to do things, be
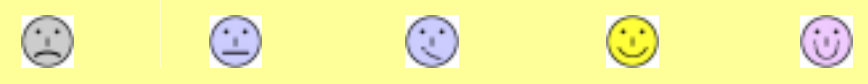
creative

4. Work on something till it is done or complete
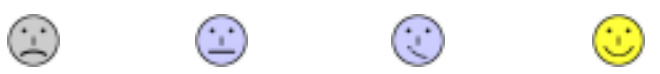

5. Feel good about yourself
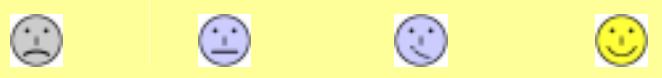

(i)

6. Really focus on school work
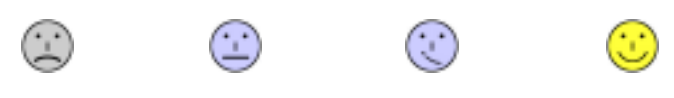

(i)

7. Be cooperative and kind to other students

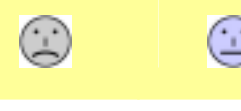

$\because \oplus$

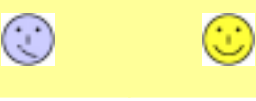

(i)

8. Keep attention on work when you are interested
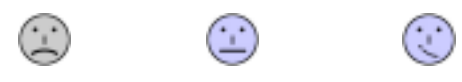

(ن)

9. Feel loose, strong, and healthy

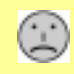

(i)

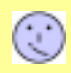

(ن)

(ii)

10. Pay attention in class or in small groups
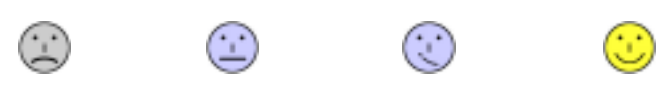

(iv)

\section{References}

Bleeker, L. (2001). Brain awareness week lessons. http://faculty.washington.edu/chudler/baw1.html

Chudler, E.H. (2001). Outside games. http://faculty.washington.edu/chudler/outside.html Educational Testing Service (2009). ETS Formative Assessment Test Bank. http://www.ets.org Fogerty, R. (2002). Brain-compatible classrooms. Arlington Heights, IL: SkyLight Professional Development. 
Gardner, H. (1983). Frames of mind: The theory of multiple intelligences. New York: Basic Books.

Gardner, H. (1999). Intelligence reframed. New York: Basic Books.

Hayes, S., Lampi, M., \& Leigh, G.K. (2002). A brain respiration manual for teachers. Las Vegas, NV: University of Nevada Cooperative Extension, CM 2-105.

Hong, H.S. (1998). Brain respiration development. New Human, 9, 8-27.

Jensen, E. (1998). Teaching with the brain in mind. Alexandra, VA: Association for Supervision \& Curriculum Development.

Jensen, E. (2001). Arts with the brain in mind. Alexandra, VA: Association for Supervision \& Curriculum Development.

Kim, S.Y., Kim, H.R., Kim, D.J., Kim, Y.Y., Park, S.K., Chase, J.H., et al. (2001). Spatio-temporal pattern of EEG in young Brain Respiration training children. American Journal of Chinese Medicine, 29.

Kim, Y.Y., Choi, J.M., Kim, S.Y., Park, S.K., Lee, S.H., \& Lee, K.H. (2001). Changes in EEG of children during brain respiration training. American Journal of Chinese Medicine, 29.

Lee, S.H. (1997). Dahn meditation. Seoul, Korea: Dahn Publishing Co.

Lee, S.H. (1998). Brian respiration. Seoul, Korea: Han Mun Hwa Publishing Co

Lee, S.H. (1999a). The way to light up your divinity. Seoul, Korea: Dahn Publishing Co.

Lee, S.H. (1999b). The way to perfect health. Seoul, Korea: Dahn Publishing Co.

Lee, S.H. (2000). Healing society. Charlottesville, VA: Walsch Books.

Lee, I. (2002a). Brain respiration: Making your brain creative, peaceful, and productive. Las Vegas, NV: Healing Society.

Lee, I. (2002b). The twelve enlightenments for healing society. Charlottesville, VA: Hampton Roads Publishing Co.

Park, S.K., Lee, S.H., \& Lee, K.H. (2000). Changes in stress-induced hormone levels during the Brain Respiration training. Manuscript.

Pert, C.B. (1997). Molecules of emotion. New York, NY: Scribner.

Skille, O., \& Wigram, T. (1995). The effects of music, vocalization, and vibration on brain and muscle tissue: Studies in vibroacoustic therapy. In T. Wigram, B. Saperston, \& R. West (eds), The Art and Science of Music Therapy, pp 23-57, Chur, Switzerland: Harwood Academic Publishers. 
Slade, N. (2001). What is "Brain Music" and what makes it different.

http://www.h2net.net/p/nslade/music/question.html

Springer, M.B. (2002). Becoming a "wiz" at brain-based teaching. Thousand Oaks, CA: Corwin Press.

Sylwester, R. (2000). A biological brain in a cultural classroom. Thousand Oaks, CA: Corwin Press.

Tileston, D.W. (2000). 10 best teaching practices. Thousand Oaks, CA: Corwin Press.

Wolfe, P. (2001). Brain matters. Alexandria, VA: Association for Supervision and Curriculum Development.

Yu, S.M., \& Chang, H.Y. (1998). Research on Brain Respirations' substantial effects. Paper presented at the Ninth Annual Korean Jungshun Science Symposium, Seoul, Korea.

(C) Copyright of Journal of Youth Development Bridging Research and Practice. Content may not be copied or emailed to multiple sites or posted to a listserv without copyright holder's express written permission. However, users may print, download or email articles for individual use. 